\title{
O "crioulo Dudu": participação política e identidade negra nas histórias de um músico cantor (1890-1920)
}

Martha Abreu

Há alguns anos venho acompanhando de perto as questões que envolvem (e envolveram) a produção de uma história da música popular no Brasil. Todo pesquisador interessado nessa temática constantemente se vê desafiado por determinadas versões já cansativamente divulgadas sobre a música popular ser o traço mais forte e mais belo da identidade brasileira, ou o samba ser a marca do que temos de mais original desde os tempos da colonização. ${ }^{1}$ Música popular e samba, apesar de costumeiramente receberem atributos e origens coloniais, só afirmam-se mesmo como gêneros e negócios entre o final do século XIX e as primeiras décadas do XX.

Se olharmos para esses marcos temporais musicais numa perspectiva mais ampla, dentro do que Paul Gilroy denominou de Atlântico Negro, é fácil verificar que essa discussão não cabe nos limites nacionais, apesar de estar diretamente ligada à construção das nações. As músicas populares nos EUA, no multicultural Caribe e na Colômbia, por exemplo, emergem nessa mesma conjuntura e envolvem-se, de forma semelhante, com as discussões intelectuais sobre o papel da presença africana nas respectivas identidades nacionais e culturais. Jazz, rumba, calipso, porro e samba possuem ainda muitos pontos de afinidade, pois, além da questão nacional, se entrelaçam com a História e ação dos descendentes de escravos e africanos na diáspora, com as lutas pela cidadania e visibilidade dos músicos negros no pós-abolição e com a emergência da nascente indústria fonográfica, que tornou viável a ampla difusão de variados gêneros musicais pelas Américas. Como afirmou Matthias Assunção, gêneros musicais até então identificados com a população negra e pobre ganharam outras dimensões nas Américas a partir do final do século XIX. ${ }^{2}$

Não pretendo aprofundar, no momento, essa rica questão comparada, mas ela é fundamental para situar e entender os significados da trajetória do músico, cantor e compositor Eduardo Sebastião das Neves, o crioulo Dudu, exatamente entre o final do século XIX e início do XX. A ascensão de músicos negros nesta conjuntura não pode ser negligenciada ou pensada apenas a partir da existência de áreas mais flexíveis para a visibilidade e mobilidade social dos descendentes de escravos. Precisa ser encaminhada numa dimensão atlântica, articulada ao intercâmbio propiciado pela instalação da indústria fonográfica em várias cidades das Américas e ao movimento cultural e político dos músicos negros.

Essa última dimensão já foi sinalizada e aprofundada por Paul Gilroy para o mundo anglo-saxão. Em O Atlântico negro, Gilroy demonstrou o quanto a música expressou um elemento fundamental da cultura política negra desde o período escravista. A música teria sido para Gilroy o principal canal de manifestação da consciência humana dos escravos e seus descendentes. Com esse olhar, não foi mero acaso, no início do século XX, a eleição, por parte das próprias lideranças negras norte-americanas e caribenhas, da música negra como o maior símbolo de uma luta política contra a opressão racial e pela pretendida autenticidade cultural. ${ }^{3}$

Para uma das mais destacadas lideranças do movimento negro nos Estados Unidos, W. E. B. Du Bois, por exemplo, em livro publicado em 1903, a música negra era a mensagem articulada do escravo para o mundo. Era a mais bela expressão da experiência humana nascida deste lado dos mares. Se ainda era "desprezada, continuava sendo a excepcional herança espiritual da nação e a maior dádiva do povo negro". ${ }^{4} \mathrm{Du}$ Bois situava a música negra, que denominou sorrow songs (canções de dor), como signo central do valor, retidão moral, integridade e autonomia, num vocabulário profundamente expresso em temáticas religiosas cristãs. Através das sorrow songs, concluiu Du Bois, perpassava "uma esperança - a fé na justiça final". 5 
Em sentido próximo, mesmo que em outro contexto religioso, um dos grandes líderes da campanha abolicionista no Brasil, André Rebouças, também havia percebido a importância da música para "a esperança e justiça final” dos africanos e seus descendentes. Em 4 de fevereiro de 1893, nas páginas do jornal Cidade do Rio, fundado por José do Patrocínio, ao procurar explicações para o riso, o canto e a dança do "negro africano", destacava os vários martírios e humilhações, que lembravam os primeiros cristãos mortos nos circos romanos:

É por isso que o negro africano ri, canta e dança sempre: olhando para o céu, vendo sempre Jesus, a fé e a esperança dos infelizes e dos desgraçados, dos que têm fome e sede de justiça, como Ele mesmo disse em sua frase de Super humana eloquência.

A resposta de Rebouças, em meio ao seu exílio e descoberta da África, ${ }^{6}$ ainda valorizava, além do canto, a importância do riso e da dança como expressōes de esperança e justiça. E é exatamente a procura dos significados políticos do riso para os afrodescendentes, ao longo da escravidão e no pós-abolição, que vem despertando a atenção e esforços de pesquisa de especialistas atuais. Não são poucos os trabalhos acadêmicos que destacaram a presença de sátiras, ironias e ridicularizações nas produçôes artísticas de afro-americanos nos Estados Unidos e Caribe como um canal fundamental para a luta contra a opressão e dominação racial. ${ }^{7}$

Nos Estados Unidos, os senhores teriam sido os alvos prediletos dessas sátiras que revelavam uma sofisticada habilidade de improvisar e avaliar as relações de poder e os conflitos raciais. Essa estratégia foi localizada em cantos de trabalho, contos e em paródias sobre a própria condição dos escravos e negros, frente aos mulatos e homens brancos. No Brasil, essas temáticas e possibilidades são encontradas nos lundus, versos e contos recolhidos por folcloristas, entre o final do século XIX e primeiras décadas do XX, em áreas de forte presença da população de descendentes de africanos e escravos. ${ }^{8} \mathrm{~A}$ obra de Dudu - suas canções e seu repertório - publicada em livros e gravada em discos, nesse mesmo período, pode ser vista como mais uma evidência dessa articulação entre música, riso e ação política no Atlântico Negro, agora também ao sul do equador.

Acompanhar essa possibilidade de articulação no Brasil abre caminhos para se pensar que a ascensão de negros no mundo musical no período pós-abolição, com lundus e sambas, não foi apenas um fenômeno local ou naturalmente determinado, como gostavam de acreditar muitos ex-senhores e as plateias brancas norte-americanas sedentas pela comicidade dos menestréis que, pintados de preto, ridicularizavam a pretensa ingenuidade e alegria dos escravos e seus descendentes. Pode ter sido uma eficaz estratégia de luta dessa população no Brasil e forte indício de que o campo musical abria possibilidades de escolha e expressão para os artistas que dialogavam com a realidade social e política de seu tempo.

Deve-se levar em consideração que o campo musical em várias cidades nas Américas, entre o final do século XIX e início do XX, afirmava-se como um local privilegiado de entretenimento, sociabilidade e negócio, tanto para editoras de livros e partituras ${ }^{9}$ como para a nascente indústria fonográfica. $\mathrm{O}$ perfil deste mercado fonográfico, no início do século XX, ainda não estava definido. Encontrava-se aberto a muitos produtos culturais, já que era difícil prever e garantir o que era possível gravar e o que efetivamente seria um bom negócio. Nos primeiros tempos, percebe-se uma grande variedade de gêneros gravados: do erudito ao popular, do estrangeiro ao nacional, das bandas e instrumentais aos artistas com vozes poderosas, dos hinos patrióticos aos discursos políticos, passando pelos duetos, gargalhadas e narrativas de destacados acontecimentos políticos e do cotidiano ${ }^{10}$ Mesmo indefinido, os empresários estrangeiros da indústria fonográfica descobriram rapidamente o sucesso das músicas populares e identificadas com a população negra de várias cidades das Américas. De fato a música popular gravada tornou-se um bom negócio e ganhou novas e inusitadas dimensões. ${ }^{11}$

As cançôes de Dudu, sem dúvida, pertencem a marcos estéticos e políticos compartilhados pelas populaçôes urbanas e pelos produtores do campo musical. Eduardo das Neves, como outros músicos, gra- 
vou valsas, modinhas e lundus; fez da música campanha patriótica republicana e política do cotidiano. Mas também teve a oportunidade - e a escolha - de articular conteúdos e versos específicos, diretamente ligados à população negra. Em meio a celebrações da pátria brasileira, há uma dimensão identitária e de luta por reconhecimento e valorização racial na sua produção musical que precisa ser reconhecida.

A obra de Dudu, seus versos, canções e repertório, afirmava uma valorização dos não brancos, das coisas crioulas, mulatas e morenas. Através do humor e da irreverência (no tratamento a antigas sinhás e patroas), os lundus de Dudu expõem o conflito racial em meio a possibilidades reais de inserção profissional de negros no mercado cultural e de diversões carioca; em meio a trocas culturais intensas numa cidade cosmopolita, como a cidade do Rio de Janeiro, que acompanhava de perto todas as novidades musicais europeias e norte-americanas. Suas canções, ao lado das de outros músicos negros contemporâneos, ${ }^{12}$ indicam alguns possíveis caminhos construídos pelos afrodescendentes para projetarem os seus sonhos e para criticarem desigualdades sociais e raciais, que pareciam perpetuar-se após o fim da escravidão.

A politização das relações raciais na obra e trajetória de Dudu está profundamente articulada com a politização das relações de gênero. Essa perspectiva de gênero no pós-abolição é ainda pouco discutida na historiografia brasileira, para além das denúncias sobre o papel subordinado das mulheres negras e mulatas. Em relação ao homem negro, as dificuldades aumentam, e, mais uma vez, Eduardo das Neves abre uma promissora janela de investigação.

Pensar as relações de gênero no pós-abolição exige, seguindo Scully e Patton, que se perceba como o processo de abolição produz, recria e naturaliza categorias e identidades de gênero. ${ }^{13}$ Nas músicas do repertório de Dudu isso pode ser bem observado através dos personagens que protagonizam suas canções. Figuras como Pai João, crioulos e crioulas, mulatas, morenas e iaiás tornam-se musas da poesia e cançóes populares, instrumentos de disputas e criação de papéis e identidades. Parecem ocupar o próprio palco - ou um palco privilegiado - dos conflitos raciais e nacionais, onde eles estão acontecendo e podem ser revertidos. Mesmo que alguns versos possam reforçar ou naturalizar as desigualdades, eles também oferecem um oportuno canal de crítica e denúncia, através da ironia e do riso. No caso do homem negro estavam em jogo a reversão de sua (histórica) falta de poder sobre as mulheres brancas e negras e a discussão das divulgadas versões sobre sua inferioridade no concorrido mercado de trabalho, ou sua pretensa disposição ao crime e à vadiagem.

Eduardo das Neves representou em sua trajetória e obra poética e musical todas essas possibilidades de atuação e expressão de um homem negro no pós-abolição.

\section{A trajetória do Crioulo Dudu}

Eduardo Sebastião das Neves teria nascido na cidade do Rio de Janeiro, no bairro de São Cristóvão, em 1874, e falecido nesta mesma cidade, em 1919, com apenas 45 anos. ${ }^{14}$ Apesar de minhas buscas, nunca consegui localizar dados mais concretos sobre a origem familiar de Dudu. Através de seus versos e histórias foi possível aproximá-lo do mundo dos libertos e do passado escravista.

Famoso cantor, tocador de choros ao violão, autor e divulgador de lundus, modinhas, serestas e chulas, organizador de livros e protagonista da indústria fonográfica no Brasil, Eduardo das Neves morreu pobre, como indicam seus memorialistas, em 1919, um pouco depois de o samba estourar como o novo estilo popular de dança e música. ${ }^{15} \mathrm{Na}$ sua carreira artística, apresentou-se em circos, casas de chopp, nos palcos dos cine-teatros, nos cafés-cantantes e nos palcos de teatros, como o Maison Moderne, de Paschoal Segreto, o Parque Rio Branco e o Apolo, onde se apresentava como "crioulo Dudu" e exibia, com elegância, segundo seus simpatizantes, um smoking azul e chapéu alto. ${ }^{16}$ Destacou-se ainda como exímio tocador de pandeiro, chocalho, cuíca e cavaquinho.

Uma de suas principais atividades, entretanto, era a de palhaço. Dudu trabalhou em reconhecidos circos da capital e do Brasil, como o Grande Circo François e o Circo Pavilhão Internacional. Há registros de que no Passeio Público, em uma espécie de café-concerto ao relento, costumava apresentar- 
se, na primeira década do século XX, com uma de suas mais famosas canções, em homenagem a Santos Dumont. ${ }^{17}$ Ao longo de sua carreira, Eduardo das Neves apresentou-se em várias cidades do Brasil. Chegou a ser empresário de um deles, tendo-lhe dado o sugestivo nome de Circo Brasil. Em meio a um negócio-diversão muito frequentado por estrangeiros e denominações internacionais, a escolha do nome revelava uma de suas grandes temáticas musicais - a Pátria. Em 1910, o Circo Brasil realizou uma grande apresentação na Rua de Santana, na Praça Onze, onde se reunia o seleto grupo musical dos amigos da Tia Ciata. Segundo o Correio da Manhã de 13 de outubro, o sucesso era certo: "a Cidade Nova iria se curvar perante a bilheteria". O "popular Eduardo das Neves", como caracterizou o jornal, "arrebatando as multidões com os seus choros ao violão", foi aplaudido no centro da capital republicana pelos seus próprios contemporâneos.

Tenho algumas indicações que os futuros astros do samba nos anos 1920, como Sinhô e João da Baiana, começaram, ainda bem jovens, a carreira artística com Dudu. Sinhô acompanhou Eduardo das Neves portando a bandeira brasileira numa famosa homenagem a Santos Dumont, em 1903. Eduardo das Neves teria gravado três sambas atribuídos a Sinhô, inclusive sua última gravação, em 10 de abril de 1919, "Só por amizade". ${ }^{18}$ José Barbosa da Silva, o "Sinhô", também residia na Cidade Nova e conviveu com os choros e atabaques das rodas de samba e candomblés da vizinhança próxima à casa de Tia Ciata. João da Bahiana (1887-1974), por sua vez, em entrevista ao Museu da Imagem do Som, declarou que havia trabalhado no circo de Dudu, comandando os garotos que animavam as cenas de Eduardo das Neves. Quantos outros futuros sambistas não teriam feito o mesmo? João da Bahiana era morador das redondezas do porto, trabalhador da estiva e filho de Tia Perciliana, da famosa confraria das Tias Baianas lideradas por Ciata.

Eduardo das Neves ainda vivia, quando a famosa música "Pelo telefone", atribuída a Donga e Mário de Almeida, fez sucesso, em 1916, mas não chegou a acompanhar a explosão do samba em ritmo nacional na década seguinte, quando Sinhô sairia consagrado. Dudu foi mesmo o rei do lundu e das canções de humor.

Até o final da vida Eduardo das Neves esteve ligado ao mundo do circo. A morte, em 11 de novembro de 1919, teria ocorrido logo depois de uma apresentação - provavelmente de lundu ao violão - no Pavilhão Fluminense, de propriedade de um empresário norte-americano. Os obituários do Jornal do Brasil e Correio da Manhã do dia 12 de novembro daquele ano dão uma boa ideia do reconhecimento do cantor para além do Rio de Janeiro. Nominalmente são citados os seus sucessos como cantor e ator dramático em circos, teatros, cinemas e cabarés dos estados do Norte, de São Paulo e Rio Grande do Sul. Em suas andanças teria conhecido uma considerável variedade de cançôes e estilos musicais, que foram incorporados ao seu repertório nas temáticas regionais.

O escritor do obituário do Jornal do Brasil também reconhecia o sucesso das canções, modinhas e lundus de Dudu, tanto as de cunho sério, patriótico e amoroso, como as de humor. Entretanto, talvez por se tratar de uma homenagem póstuma, ou por Dudu ter mesmo investido nesta imagem, ao menos no final da vida, atribuía o sucesso ao fato de o cantor sempre ter observado "a maior moralidade". Considerava também que o cantor teria contribuído muito para a qualidade das gravações na Casa Edison, pois o timbre de sua voz era insubstituível. É no mínimo curioso que os jornais não tenham comentado o sucesso de seus livros publicados.

Outro bom motivo para a investigação da trajetória musical de Eduardo das Neves são as publicações de seu repertório em livros. Antes de se destacar no mundo fonográfico, a partir de 1902, Dudu já fazia sucesso, como demonstram as diversas ediçôes de alguns livros que eram identificados como de sua autoria e traziam seu nome em letras bem visíveis. Publicou, pelo que eu tenha registro, cinco livros, reunindo canções, muitas delas de sua autoria, outras de domínio público, cantadas em teatros, trazidas de várias partes do Brasil e do passado escravista.

Pela popular Editora Quaresma do Rio de Janeiro, publicou $O$ cantor das modinhas brasileiras (1927/1937, sem referência ao número da edição), provavelmente o primeiro a divulgar suas canções, ${ }^{19}$ 
Trovador da malandragem (1926, 2a edição, com canções registradas entre 1889 e 1902) e Mistérios do violão (1905). Na capa deste último, além do nome do autor em evidência, é valorizado, no subtítulo, o "grandioso e extraordinário repertório de Modinhas Brasileiras de Eduardo das Neves" e a sua autoria em publicações anteriores, como $O$ cantor das modinhas brasileiras, o Trovador da malandragem e a marcha de Santos Dumont. No livro Trovador da malandragem, publicado provavelmente entre $1903 \mathrm{e}$ 1904, também há destaque para sua publicação anterior, $O$ cantor das modinhas brasileiras, e para o que o livro trazia: uma "nova coleção de modinhas brasileiras, lundus, recitativos, monólogos, cançonetas, tremeliques e choros da Cidade Nova; casos passados com os mais célebres e famigerados representantes do invencível povo da Lyra, etc".

Pela também popular editora C. Teixeira, de São Paulo, localizei $O$ cancioneiro popular moderno $\left(10^{\mathrm{a}}\right.$ edição de 1921) e O trovador popular moderno (16 edição de 1925). Esses dois livros publicados pela C. Teixeira indicavam na capa que o repertório das "extraordinárias modinhas" era também de outro famoso trovador, contemporâneo e, segundo alguns memorialistas, concorrente de Dudu na Casa Edison, Baiano. Todos os livros citados possuem mais de 120 páginas!

No livro em que se autoproclamou "Trovador da Malandragem", identificou-se também como "O Crioulo Dudu das Neves", título de uma de suas composiçôes. ${ }^{20}$ Através da formidável letra de "O crioulo", que não chegou a ser gravada em disco, tomamos conhecimento de uma espécie de autobiografia e podemos perceber como um "crioulo" tinha em grande conta a sua autoestima. Aliás, segundo os seus poucos biógrafos, gostava de vestir-se com muita elegância, de fraque e cartola.

Das Neves declara ter escrito a letra, em 1900, no bairro do Engenho Novo (Estação de Piedade/ Méier), onde provavelmente residia com sua mulher e filho pequeno (o futuro tipógrafo e reconhecido cantor Cândido das Neves). Esse bairro, entre 1890 e 1906, era já o segundo mais populoso da cidade, depois do Engenho Velho, em função da grande procura da população por moradias mais baratas. ${ }^{21}$

Logo no início da canção afirmava que, desde "molecote", já tinha "jeitinho para tocar violão"; foi "crescendo", "aprendendo e se metendo na malandragem". O sucesso parece ter sido considerável, pois afirmou que, "quando colocava a mão na lira", "as moreninhas ficavam gostando de ver o crioulo preludiar". Depois de revelar que trabalhara na Estrada de Ferro e no Corpo de Bombeiros, e de ambos os lugares ter sido afastado por "mau" comportamento, afirmou que não se agastava de ser "crioulo". Não tinha "mau resultado". "Crioulo sendo dengoso" trazia "as mulatas de canto chorado". ${ }^{22}$

Para reforçar sua positiva imagem de "crioulo dengoso" - em contraposição aos fracassos como trabalhador - contava que havia ido a "certo casamento". Lá, depois de ter "puxado ciência no violáo", a noiva, encantada, teria declarado para a madrinha:

"Este crioulo é a minha perdição"... "Como se chama?"

"Sou o crioulo Dudu das Neves".

Eduardo das Neves realmente fez parte do Corpo de Bombeiros, na 4ª Companhia, como vários outros homens negros de sua condição e habilidade musical, entre o final de 1892 e o início de 1893. Na canção "O Crioulo" forneceu uma explicação para o fato: como "um filho" de seu pai era do "Grupo dos Estradeiros", ele foi para a $4^{a}$ Companhia. Mas lá não ficou muito tempo, como reconheceu.

Dificilmente o Corpo de Bombeiros poderia aceitar, como ele mesmo cantou, que preludiasse ao violão, enquanto "esperava equipado e de prontidão". De fato, conforme o memorialista Jota Efegê, que conseguiu ter acesso ao seu prontuário, Dudu foi mesmo expulso do Corpo de Bombeiros, após prisões sucessivas por não largar o seu violão. Segundo consta, depois de ingressar em dezembro de 1892, frequentou fardado as rodas de boêmios e chorões, nas noitadas em plena rua; ridicularizou superiores, portou-se inconvenientemente em um bonde e fugiu mais de uma vez para tocar violão. O praça n. 398 parecia não melhorar de comportamento. Em 19 de abril de 1893 foi preso mais uma vez por ter sido encontrado fardado, "tocando violão em uma venda". Finalmente, a ordem do dia n. 132 de 12 de 
maio de 1893 determinava a sua exclusão "por incorrigível e indigna de pertencer às fileiras do Corpo de Bombeiros". ${ }^{23}$ Eduardo das Neves devia ter então 19 anos.

Saindo do Corpo de Bombeiros, empregou-se, como guarda-freios, na Estrada de Ferro Central do Brasil. Na letra de "O crioulo" declarava ter sido "guarda-freio destemido", mas, depois "daquela grande greve", acabou sendo "demitido". Pela sua própria explicação, havia um "chefe" que o "trazia sempre na pista", "não gostava da sua ginga" e apontou-o "como grevista". Apesar de não ter encontrado registros dessa "grande greve", a pesquisa de Teresa Meade indica que houve muitas delas na primeira década republicana, principalmente no setor de serviços públicos, como transportes urbanos e ferroviários. Uma das mais poderosas uniões de trabalhadores, justificando tais mobilizaçôes, era exatamente a dos funcionários da Central do Brasil, grande empresa no transporte do café e pessoas no final do século XIX. ${ }^{24}$

Após sua "demissão", Eduardo das Neves finalmente teria conseguido dedicar-se completamente ao violão e aos espetáculos. Não precisaria mais conciliar suas atividades de músico com as de trabalhador regular, apesar de nunca ter conseguido juntar muito dinheiro.

Sua apresentação aos palcos teatrais, na última década do século XIX - no Apolo - teria sido pelas mãos do também artista, identificado algumas vezes como negro, Xisto Bahia (1841-1894). Xisto mereceu de Dudu diversas referências em seus livros e gravações, além da presença constante em seu repertório. Em 1895, Eduardo das Neves já conhecia Catulo da Paixão Cearense e o seu primeiro livro pela Quaresma, $O$ cantor das modinhas brasileiras, havia sido publicado. Um anúncio do Circo-Pavilhão Internacional, armado em Botafogo, em fins de 1897, demonstrava que o cantor já era um sucesso nos picadeiros: "O primeiro palhaço brasileiro fará as delícias da noite com suas magníficas cançôes e lundus acompanhado com seu choroso violão". ${ }^{25}$ Logo depois viriam os livros e os discos com a indústria fonográfica a partir de 1902.

Entre o serviço no Corpo de Bombeiros e o trabalho na Central, provavelmente, Eduardo das Neves participou da Guarda Nacional, onde ganhou o título de capitão, pois teria combatido "valentemente", ao lado de Floriano Peixoto, na Revolta da Armada, no período de setembro de 1893 a março 1894. Pela fotografia publicada por Jota Efegê em O Jornal de 3 de julho de 1966, e os comentários de memorialistas, Das Neves, de vez em quando, ostentava o seu uniforme de capitão, com muito orgulho, demonstrando conhecer os significados políticos que tal vestimenta trazia.

Um dos mais ricos informantes de Eduardo das Neves foi, sem dúvida, Vagalume, Francisco Guimarães (1877-1947) ${ }^{26}$ Famoso repórter de polícia e cronista de carnaval do Jornal do Brasil, Vagalume teria conhecido o "Diamante Negro" (título que conferiu a Dudu) no início do século XX e o teria ajudado a escrever e revisar algumas letras de canções, como "Pega na chaleira", segundo suas observações. ${ }^{27}$ De acordo com Vagalume, uma das duas maiores aspiraçôes de Eduardo das Neves era ser oficial da Guarda Nacional. A outra, era ser proprietário de um circo. ${ }^{28}$ Sem dúvida, pelo olhar de intelectuais de prestígio, como veremos com João do Rio, essas duas aspirações pareciam pretensiosas demais para um "crioulo malandro", na virada do século XIX para o XX: servir à pátria e tornar-se empresário.

Mas Dudu ainda pode ostentar na vida outras pretensóes: publicou livros e fez um contrato com a Casa Edison, em 1902. A partir daí passou a fazer parte, até o final da vida, do primeiro grupo de músicos profissionais dessa importante empresa de venda de partituras e discos, ao lado de Baiano, Cadete, Nozinho, Mário Pinheiro e Geraldo Magalhães. ${ }^{29}$

Apesar do sucesso, a vida artística não foi fácil. Problemas financeiros e situações de preconceito racial são registradas pelos memorialistas e pela imprensa no momento de sua morte. Vagalume assinala que o seu Circo Brasil lhe trouxe muitos aborrecimentos e enormes sacrifícios, pois o "sócio espertalhão [...] esperava o momento em que Eduardo estava em cena, para arrecadar todo o dinheiro entrado na bilheteria" ${ }^{30}$ Para confirmar essa história, o jornalista afirma que um dos maiores juristas do período, o Dr. Evaristo de Moraes, seu grande amigo, tinha sido testemunha do que aconteceu. ${ }^{31}$

Para Vagalume, demonstrando partilhar uma identidade negra com o cantor, Eduardo das Neves havia honrado a "raça" a que se orgulhava de pertencer. Na sua avaliação, não teria existido plateia, "por 
mais exigente que fosse, que não o recebesse com delirantes ovações", mesmo com o preconceito que existia contra os artistas que também se destacavam nos circos. Valorizando a identidade racial de Dudu, é interessante notar que o jornalista Vagalume só tenha mencionado o possível preconceito da plateia com artistas de circo!

Almirante, Henrique Domingues (1908-1980), outro importante memorialista da música popular, é quem relata mais diretamente situações de preconceito racial sofridas por Dudu. Em 1915, no Rio Grande do Sul, em uma excursão, Eduardo das Neves teria tido problemas com o dono de um bilhar, que não queria atendê-lo, presumidamente, por ser negro. Eduardo, então, teria procurado o delegado de polícia local que obrigou o proprietário a servi-lo. O cantor, com euforia, jogara a partida até o final. Depois de pagar a conta, teria bradado um forte 'viva o Brasil', "que ecoou no salão como um veemente grito de protesto". ${ }^{32}$

Ainda uma outra vez, e não só no Rio Grande do Sul, encontrei registros sobre preconceito racial. Quanto foi fundada a Casa dos Artistas, em 24 de agosto de 1918, Eduardo das Neves, segundo Almirante, logo teria procurado, "com entusiasmo", ingressar naquela instituição. Mas sua pretensão teria esbarrado "na má vontade do então presidente da Casa". Só conseguiria fazer parte da Casa depois da intervenção de outras "pessoas sensatas". No dia em que recebeu o seu diploma de sócio, teria ficado dominado por uma alegria, quase infantil, procurando mostrar o diploma a todos os seus íntimos...". ${ }^{33}$

Mesmo sem ter conseguido localizar a vitoriosa inscrição de Eduardo das Neves na referida Casa, depois de muitas tentativas, o obituário do jornal Correio da Manhã confirmou toda a história, pois salientou que, por ter trabalhado dois anos antes de sua morte em uma companhia de revista no Teatro São Paulo, havia pleiteado a admissão como sócio. Entretanto, sem comentar explicitamente os motivos, o jornal declarava que só havia sido aceito há menos de um mês, em função da "oposição" - presumidamente por sua cor - que um grupo de associados lhe moveu. A certidão de óbito de Eduardo das Neves reconheceria definitivamente a sua reivindicação: a profissão declarada por seu filho, em 10 de novembro de 1919, dia de sua morte, era a de artista. Das Neves procurou reconhecimento como artista, e como artista negro.

Apesar das palavras elogiosas em seus livros e nos obituários dos jornais, e da variedade dos relacionamentos de Eduardo das Neves, desde músicos populares e capoeiras a prestigiosos intelectuais, como Mello Moraes Filho, Afonso Arinos, Evaristo de Moares e o jovem Heitor Villa-Lobos, o trovador não era uma unanimidade. Pela leitura dos memorialistas, fica evidente que Eduardo das Neves participava de um meio artístico de menor prestígio, pois havia uma nítida estratificação da sociabilidade e do mercado culturais na cidade do Rio de Janeiro. Eduardo das Neves e seus amigos violeiros, segundo Luiz Edmundo, reuniam-se na Livraria Quaresma, e não na charmosa e poderosa livraria Garnier, grande editora de literatura, onde podiam ser encontrados Machado de Assis, João Ribeiro, Duque Estrada e Mário Pederneiras.

A Livraria Quaresma era uma "casa editora que outrora explorava, com sucesso e proveito, o pitoresco do folclore nacional". ${ }^{4}$ Para Luiz Edmundo, editava "baixas letras" e tinha como objetivo abrasileirar o comércio de livros. Lançava discursos, manual dos namorados, dicas para o jogo do bicho, livros sobre feitiçarias, melhores maneiras de se discursar em tom elevado, novelas populares e exóticas brochuras, com títulos apavorantes, tais como Elzira, a morta virgem, e Maria, a desgraçada. Uma boa parte de sua produção era de modinhas para trovadores, como as de Dudu. A freguesia dessa livraria, formada por interessados no gênero, seria bem mais diversificada, pela avaliação do memorialista, já que composta de negros e brancos. ${ }^{35}$ Nas memórias preconceituosas de Brito Broca, os sucessos da editora Quaresma dependiam muito de Dudu, da "inventiva daquele preto de cara achatada". ${ }^{36}$

No meio musical e artístico, apesar do trânsito dos músicos populares em ambientes requintados, os conflitos em torno da valorização, ou não, de determinados gêneros musicais e do reconhecimento social dos artistas não eram pequenos. Existiam palcos variados e hierarquizados, como os "music-hall", 
os teatros de revista e os circos de cavalinhos. O maior palco de Eduardo das Neves, o circo, também conhecido como circo de cavalinhos, foi o único que recebeu de Luiz Edmundo a qualificação de uma enorme babel, frequentado por "gente de todas as raças e nações". Era, no fundo, a diversão de quem não podia ir ao teatro ou ao "music-hall". ${ }^{37}$

\section{A produção musical}

Pelas publicaçóes de Eduardo das Neves e pelos discos da Casa Edison, hoje guardados no Instituto Moreira Sales, no Rio de Janeiro, fica evidente que sua produção musical foi grande e variada, destacando-se lundus, modinhas, serestas, choros, marchas, cançonetas, sambas, valsas, chulas, cateretês, maxixes e cenas cômicas. ${ }^{38}$ Trovador, cantor e compositor, uma das tarefas mais difíceis é determinar o que realmente era de sua autoria ou o que cantava dos outros, divulgando músicas e letras de diferentes procedências. Nessa época a questão da autoria estava apenas começando a ser discutida. ${ }^{39}$

Dudu das Neves percebeu o problema e brigou pelo reconhecimento de sua autoria em algumas delas. ${ }^{40} \mathrm{Na}$ avaliação do reconhecido escritor João do Rio, mesmo que em tom pejorativo, o cantor demonstrava uma "convicção definitiva" sobre o que era de sua autoria, diferentemente de outros, como o também famoso cantor, Baiano, contratado pela Casa Edison. ${ }^{41}$ Aliás, para o jornalista, Dudu era um homem de convicçôes, como a que havia exposto em uma canção (certamente a do "crioulo"), quando, depois de contar intimidades de sua vida, deixou claro que uma senhora estava loucamente apaixonada pela sua voz. $\mathrm{Na}$ visão de Dudu, como vimos, não era apenas pela sua voz.

O problema da autoria foi diretamente enfrentado por Eduardo das Neves no Prefácio do livro $O$ trovador da malandragem, onde, mais uma vez, demonstrou um grande convencimento pelo seu valor e capacidade. Essa postura o teria motivado a reclamar com o Sr. Fred Figner, então proprietário da Casa Edison do Rio de Janeiro e representante da Talking Machine Odeon, depois de ter ouvido uma composição sua - "O 5 de novembro" - tão adulterada, que nada se entendia. Ao cantar algumas modinhas em um dos fonógrafos do estabelecimento comercial de Figner, o empresário o teria contratado para cantar todas as suas produçôes nos aparelhos que colocava à venda. Em seguida, deve ter vindo o convite para as gravações.

Com uma linguagem simples e direta, Eduardo das Neves, no livro $O$ trovador da malandragem, se perguntava por que motivo não se acreditava na sua autoria de certas composições - choros, ele menciona - do gosto do público, "cantadas por toda a gente e em toda parte - desde nobres salóes, até pelas esquinas, em horas mortas da noite".

Foi isso que sucedeu com minhas hoje popularíssimas modinhas: "O Aumento das passagens", "O bombardeiro", "O 5 de novembro" ou o "Marechal", "A Guerra de Canudos", "A carne fresca", "O cólera", "A gargalhada hispano-americana", "Uma entrevista com Fegoli” e dezenas de outras modinhas que o Zé do Povo aprecia e canta.

Sim! Por que razão duvidais que sejam minhas, exclusivamente minhas? Nem tão boas, nem tão notáveis são elas para que não possam ser de minha lavra.

O muito merecimento que têm (e é por isso que tanto sucesso fazem) é que eu as faço segundo a oportunidade, à proporção que os fatos vão ocorrendo, enquanto a coisa é nova e está no domínio público). É o que se chama bater o malho, enquanto o ferro está quente...

E, no entanto, apesar das minhas pobres composições nada prestarem, há por aí uns tipos ainda mais ignorantes do que eu, que se intitulam pais de meus filhos, autores de minhas obras, como se dá com o "Aumento das passagens", "O 5 de novembro", "A gargalhada do Biela".

Como porém, não entendem do riscado, estropiam tudo horrorosamente.

Faço essa declaração... para evitar dúvidas...

O seu, a seu dono.

Sinto muito ter que passar-vos este sabonete, mas... chorar não posso. Não quero que se diga por aí que sou um idiota, um trovador que escreve e canta cousas sem sentido, modinhas sem pé, nem cabeça. 
Essa definição sobre o seu estilo - "bater o malho, enquanto o ferro está quente" - transforma a produção musical de Eduardo das Neves em uma espécie de crônica da cidade e do país na época. Se essa característica talvez explique o desinteresse dos músicos de hoje pela sua obra, por outro lado confere a ela uma riqueza extraordinária sob o ponto de vista do historiador. Mais ainda, situa o artista trovador numa forma musical e artística muito difundida nos meios urbanos, desde o último quarto do século XIX, os teatros de revista e as revistas do ano, que discutiam os problemas da cidade, assim como os seus políticos e projetos de modernização.

Mesmo apresentando lundus, muito humor e crítica social, além das belas mulatas, essa linguagem artística das revistas era comandada por intelectuais de peso, como Artur Azevedo, por exemplo, e atraía um público urbano amplo e diversificado. ${ }^{42}$ Dialogando com esse mundo, inclusive fazendo parte dele, Eduardo das Neves lhe conferiu novos sentidos e dimensões, pois também levava para diferentes palcos, picadeiros, rodas de samba, serenatas, préstitos carnavalescos, outras linguagens musicais e poéticas, assim como divulgava para amplos setores sociais novos gêneros e estilos, envolvidos, como ele mesmo afirma, na "oportunidade, à proporção que os fatos vão ocorrendo, enquanto a coisa é nova e está no domínio público".

O próprio reconhecimento de que suas canções "não eram tão boas, nem tão notáveis" nos faz pensar que Dudu tinha a certeza de que não era um literato de grande estirpe, mas tinha orgulho da produção de um crioulo "popularíssimo", capaz de ter público e sucesso próprios. Parecia prezar a opinião que teriam sobre ele: "não quero que se diga por aí que sou um idiota, um trovador que escreve e canta cousas sem sentido, modinhas sem pé, nem cabeça”. Existiriam "tipos ainda mais ignorantes" que andavam se intitulando pais de seus filhos, ou melhor, autores de suas obras.

É digno de nota que os exemplos escolhidos para afirmar sua autoria tenham sido títulos ligados a questōes políticas nacionais, como "A Guerra de Canudos", "O 5 de Novembro", o "Bombardeiro", e problemas urbanos importantes do momento, como "O aumento das passagens", a "Carne fresca" e o "Cólera". Essas escolhas parecem indicar que Dudu tinha indiscutível consciência dos temas de importância nacional, que poderiam valorizar sua obra. Por outro lado, suas declarações também revelam uma razoável indignação pelo não reconhecimento de que um "crioulo" pudesse falar de políticos, eleições, costumes nacionais, problemas urbanos e política externa, como a "Gargalhada hispano-americana".

Entender os significados das escolhas do repertório de Eduardo das Neves não é tarefa fácil. Sem dúvida, em grande parte, relacionavam-se com as decisões pessoais do artista, como ele mesmo fez questão de demonstrar. Mas não podemos afastar completamente a influência do próprio público e dos proprietários dos negócios de livros e discos. Grande parte das cançôes publicadas em seus livros, ou gravadas pelo cantor, não possui indicação de autor ou é considerada como de autoria desconhecida. As escolhas de Dudu, além das que ele reconhecia como de sua autoria, recaíam sobre canções e motivos que já circulavam em "domínio público", como ele mesmo admitia.

Entre os temas das cançôes publicadas em livros e gravadas em disco há, pelo que apurei até o momento, mais aproximaçôes do que diferenças, o que fortalece a ideia de que a indústria fonográfica, nos seus primeiros tempos, seguia de perto o perfil dos livros e publicaçôes de canções populares. Destacam-se em ambos os suportes culturais, com vantagem, as cançôes que falam de amor. Desfilam, entre centenas de versos, ingratidões, juras, saudades, romances frustrados e dezenas de musas, alvas e sinhás, francesas e espanholas, morenas e mulatas.

Temas sociais também estão bem representados nos dois veículos de divulgação. Em geral, através do humor, ironia e irreverência, encontramos canções com apreciações sobre a modernidade urbana (os automóveis, o bonde, uma quermesse, a passagem de um cometa, uma confusão em um bonde, um clube de regatas); com narrativas sobre os problemas da cidade (como as reformas urbanas, o aumento das passagens, a exposição, o malandro, os paladinos da cidade nova, uma casa de pasto, a vacina obrigatória, a carne fresca, a vacina e os ratos da peste bubônica, a festa da Penha); com comentários de as- 
suntos políticos cotidianos (como a lei do selo, o desvio de dinheiro, a reforma da higiene, os aluguéis, as eleições, o voluntário, os malandros, a capoeira e o "pega na chaleira" - a clássica bajulação aos políticos diretamente ligada aos costumes do político gaúcho Pinheiro Machado) -, e com sátiras a respeito de certos personagens e situações cotidianas (como um barão, um padre e um bispo; uma romaria, uma casa de pasto, um baile no céu, um maxixe e os chapéus).

Temas regionais e folclóricos, em tom mais sério, muito em voga entre setores intelectualizados no início do século XX, como, por exemplo, "Canção da cabocla", "Flor do Norte", "Gaúcho", "Pernambuco é minha terra", "Cateretê paulista", "Luar do Sertão", "Cabocla do Caxangá”, também despontam nos dois tipos de produção de Eduardo das Neves. Da mesma forma, há cançôes com temas patrióticos e políticos mais amplos, como veremos.

A partir de sua variada produção, privilegiei três temáticas presentes na obra de Eduardo das Neves e articuladas ao trabalho de revisão de algumas teses muito difundidas sobre o primeiro período republicano: o patriotismo, as relações raciais e a identidade do homem negro.

\section{Sobre o patriotismo}

Em meio a canções cheias de comicidade, emergem algumas em tom sério e musicalmente próximas aos hinos oficiais. Nelas encontramos uma grande valorização e idealização da pátria, dos brasileiros, de suas regiōes, e, em última instância, da própria República, ao menos a que ele defendia. Assim, localizei versos sobre a revolução no Paraná, os feitos de Santos Dumont, o naufrágio do Aquidaban e a chegada dos "gigantes do mar" para a "defesa do nosso Brasil”, como os navios "Minas Gerais" e "São Paulo"; homenagens poéticas à força dos militares Floriano Peixoto, Marechal Bittencourt e Plácido de Castro (defensor do Acre), assim como à importância do Barão do Rio Branco. Tornaram-se cançôes na obra de Eduardo das Neves até mesmo problemas internacionais, como os conflitos anglo-boer e hispano-americano, e um apelo para a "Volta à Pátria" do Imperador.

As homenagens aos heróis nacionais dialogam, pelo tom patriótico e por várias expressões - tais como "guerreiro", "brado que ecoa", "local viril", "peito que inflama” e "mãe pátria" - com os versos do hino nacional de Osório Duque Estrada, ${ }^{43}$ compostos em época próxima às canções patrióticas de Dudu. Percebe-se nos versos de Dudu a valorização da República e dos feitos individuais dos filhos da "pátria mãe". Pelo que indica a obra de Eduardo das Neves, a atmosfera de patriotismo na recém-proclamada República não estava só nas palavras de eruditos republicanos, como Estrada. A Pátria era palavra de ordem nas canções populares da Primeira República.

Com exceção de Santos Dumont, os líderes são homenageados após a morte. No caso dos militares, os três foram líderes da Guerra do Paraguai. Eduardo das Neves sabia escolher, nas primeiras décadas republicanas, os heróis a serem cantados: líderes populares, militares e com grandes feitos. A Guerra do Paraguai teria sido um grande celeiro dos heróis da nação. ${ }^{44}$

Na canção denominada "O Marechal de Ferro", o subtítulo indica a homenagem à "saudosa memória do marechal Floriano Peixoto, ${ }^{45}$ falecido em 29 de junho de 1895.46 Para quem fez parte do apoio militar ao Marechal, Dudu relembra, com emoção, seus feitos e glórias. Valoriza a força de Alagoas frente à própria Europa, relembra a traição dos que se levantaram contra o herói e ainda faz referência a um outro militar, o Marquês de Herval, que também teve destacada atuação na Guerra do Paraguai. Os versos para Floriano foram publicados no Trovador da malandragem, mas não foram registrados pela indústria fonográfica.

Quando ele apareceu, altivo e sobranceiro,

Valente como as armas, beijando o pavilhão,

A pátria suspirou, dizendo: Ele é guerreiro,

É marechal de ferro, escudo da nação!

O brado fluminense ecoou por toda a parte... 
Rompem-se os astros nublados; somem-se turvas garoas;

Ele empunhando a espada, qual valente Bonaparte,

Pergunta ao Mundo: - Conhecem-me... Sou filho de Alagoas!

Sim sou filho de Alagoas, esse estado do Brasil,

Que é pequenino, é verdade, mas poderoso e viril;

Jogarei de espada e capa, e hei de mostrar como a Europa.

Não me ganha nem centil.

E avante Brasileiros! Em prol da pátria co’ardor,

A bem de vosso direito, aniquilar o traidor!

Vamos! A Pátria, reclama... Quem seu peito não inflama

Para dar à mãe vigor?

Deusa que o gênio idolatra, pois dela é que ele nasceu

Essa mãe que se diz Pátria, que por ela Herval morreu

Partamos nesse momento! Eu vos darei elemento!

Quem tem o poder sou eu!

$\mathrm{Na}$ homenagem ao Marechal Bittencourt, assassinado em 5 de novembro de 1897, a data torna-se o próprio título da canção, que ainda era publicada na década de $1920 .{ }^{47}$ Eduardo das Neves, nos versos que reivindica, com ênfase, como de sua autoria, expressa, além do pranto e a mágoa de todo o Brasil, o choro do "bravo exército pelo audaz guerreiro". Preocupa-se também com o futuro da República após tal crise.

O minha República

prevê tais perigos!!

Paralisa o braço

de teus inimigos!!

Ó manto sagrado

cobre esse caixão!

Não te mancha o sangue,

que é do nosso irmão.

Venho dar meus pêsames

como brasileiro,

ao valente exército!

ao Brasil inteiro!

A família em prantos

queria os receber

pela nobre vítima,

filha do dever.

O Marechal Bittencourt, destacado militar na batalha do Tuiuti, em 1866, havia sido assassinado, em 5 de novembro, num atentado destinado ao Presidente Prudente de Morais. Sua morte teria mesmo consternado o país e ameaçado o clima de segurança que se iniciava após os agitados anos do Marechal Floriano Peixoto. A homenagem de Eduardo das Neves não mencionava uma das últimas façanhas do então marechal: a derrota de Canudos, em 1897, dois meses depois de sua chegada ao território baiano.

Sem dúvida, não é fácil explicar completamente a lógica de escolha dos heróis cantados por das $\mathrm{Ne}$ ves. Se a participação na Guerra do Paraguai parece unir os militares, sua ação política posterior não justificaria as homenagens. O Marechal Bittencourt, por exemplo, nunca aderiu ao círculo do Marechal de Ferro, tão estimado por Dudu. Mas seguindo a lógica de valorização dos acontecimentos do momento, a morte de Bittencourt parece realmente ter tido grande repercussão. A canção tornou-se um dos maiores sucessos de Dudu, como indicam seus obituários. 
A homenagem a Santos Dumont é mais justificável, pois foi recebido como herói por toda a cidade e por vários políticos importantes, depois de seus feitos na França com um balâo dirigível. Para Dudu, Santos Dumont era a glória maior do século XX! Era um brasileiro, da "terra amada do índio audaz guerreiro". ${ }^{48}$ O Barão do Rio Branco, por sua vez, "grande diplomata brasileiro", era o "sentinela do pavilhão brasileiro"; a "pátria amada" chorava seu luto. Santos Dumont foi publicado em livros e discos. O Barão foi cantado apenas em discos.

Outros heróis pátrios contemporâneos, entretanto, com perfil político e biográfico próximos, não chegaram a ser cantados e homenageados após suas mortes, como Joaquim Nabuco e Rui Barbosa, pelo que eu tenha notícia. Sempre é bom considerar a hipótese de que Eduardo das Neves não estivesse no Rio de Janeiro em alguns períodos, em função de suas excursões pelo Brasil em companhias de teatro e circo.

Como entender todas as escolhas de Dudu? Sem dúvida há limites evidentes na análise de suas canções. Por ora, o que interessa - ou o que é possível saber - é que um crioulo podia - e queria - posar de patriota e cantar a República, contribuindo para a divulgação de heróis e de símbolos nacionais. ${ }^{49}$ Seus versos patrióticos eram muito vendidos, tanto em livros como em discos. Sua produção indica que havia um público interessado nessas temáticas para desespero de certos importantes intelectuais da época, como João do Rio.

João do Rio (1881-1921), badalado intelectual da chamada Belle Époque carioca, membro da Academia Brasileira de Letras, jornalista e cronista sensível da cidade, percebeu e registrou, numa crônica da revista Kosmos, ${ }^{50}$ em agosto de 1905, a popularidade dos "poetas das calçadas". Sensível cronista, ainda que preconceituoso, o autor reparou que nas "quadras mancas" viviam o patriotismo, a fé, a pilhéria e o desejo da "populaça". Dos "versos falhos, com um milhão de erros de gramática e metrificação", fazia-se a "sinfonia da cidade, proteiforme e sentimental".

Para a sorte deste trabalho, João do Rio considerou que a "musa das ruas" tinha seus preferidos, estetas e críticos. Dentre outros, como o Geraldo e o já conhecido Catulo da Paixão Cearense, destacavase Eduardo das Neves. Na avaliação de João do Rio, entre os poetas das ruas, Eduardo das Neves era o que havia levado mais longe a sua fantasia. Pelo que sabia, por testemunho próprio, Das Neves tornarase membro do "music-hall", andava de smoking azul e chapéu de seda e, sobretudo, chegara a publicar um livro intitulado Trovador da malandragem. E o digno membro da ABL só conhecia um livro! Devia mesmo ser muita pretensão de um poeta e músico negro das ruas.

Em 1905, a editora que publicara o referido livro - a Quaresma - também reconhecia que Eduardo das Neves era um "poeta popular, bardo do povo", mas não demonstrou o mesmo preconceito de João do Rio a respeito da avaliação de que o cantor das ruas teria levado muito longe a sua fantasia. Certamente mais preocupada com a vendagem e ampla circulação da terceira obra do poeta, Mistérios do violão (as anteriores foram Cantor de modinhas e Trovador da malandragem), apostava num estupendo sucesso. Nas palavras do editor,

ninguém lhe pode imitar. Como os artistas populares de Montmartre, Eduardo se apresenta nos circos de cavalinhos, nos cafés-cantantes, no Parque Rio Branco em todas as casas de diversão... Suas canções não eram só tocadas pelos violóes dos "cafajestes e do Povo da Lira", mas em muitas casas de família, nos aristocráticos salóes de Petrópolis, Botafogo, Laranjeiras, Tijuca etc..., senhoritas distintíssimas, e virtuoses conhecidos fazem-se ouvir em noites de recepção, nas cançonetas de Eduardo das Neves.

Apesar do trânsito em diferentes ambientes, a Editora Quaresma categoricamente afirmava que o artista era um verdadeiro trovador popular:

não será um poeta impecável, um Bilac, um Medeiros de Albuquerque, um Raimundo Correia, um Luiz Delfino, um Artur Azevedo, um Murat, um Figueiredo Pimentel, mas é com certeza um poeta, na legítima acepção do termo, como o público os aprecia, os lê, os decora, e os traz constantemente na imaginação. 
A estratégia de comparar os "poetas impecáveis" e os poetas do povo, procurando valorizar as qualidades dos últimos, não estava apenas na mente do esperto editor Quaresma. João do Rio também estabelecia comparações, mas em sentido bem diferente. Lamentava que os primeiros não estavam mais conseguindo agradar, já que não faziam "versos para toda gente". Os poetas do povo, em compensação, ao brotarem "na calçada, como cogumelos, tinham uma só preocupação séria - cantar. Cantavam como as cigarras e o canto dava-lhes "para viver no eterno verão desta terra abundante". Quando não havia dinheiro, inventavam versos para uma música conhecida, mandavam imprimir e vendiam tudo por dois tostôes. Com uma certa dose de inveja, João do Rio reconhecia que ninguém poderia ficar surpreso com o fato de que imprimiam e esgotavam edições, milheiros e milheiros de exemplares. Imprimiam como qualquer poeta, mas apenas eles vendiam. A maioria dos outros poetas (presumidamente os "grandes poetas") acabava oferecendo seus poemas gratuitamente aos amigos. João do Rio estava, no fundo, reconhecendo e criticando a existência de um novo mercado editorial, muito bem representado pela Editora Quaresma: pujante, mas muito pouco seletivo em seu público.

João do Rio não perdoava os versos irônicos dos "poetas das calçadas”. Desqualificava completamente o seu patriotismo. Para o erudito escritor, os poetas sem nome, diferentemente dos jornalistas, não exibiam a infâmia dos políticos e as fraquezas dos partidos. "A musa urbana enaltece sempre os seus homens e quando odeia, oculta o ódio para não o mostrar aos de fora”. Na avaliação de João do Rio, poetas, como Eduardo das Neves, expunham um "patriotismo bizarro", cheio de elogios aos presidentes: o bom Prudente, o bom Floriano, o bom Campos Sales. ${ }^{51}$

Sem dúvida, as críticas de João do Rio fazem parte das disputas políticas e artísticas daquele tempo. Podem conter certa verdade, mas não toda a verdade. Já dei vários exemplos de canções divulgadas por Dudu que traziam ásperas críticas aos costumes, aos problemas da cidade e dos políticos. Nas letras e músicas de Dudu é possível também ouvir as lutas políticas do momento ou os "Ecos da Política", como diria Marcelo Magalhães, os ecos do "fazer política" na cidade do Rio de Janeiro entre o final do século XIX e início do XX..$^{52}$ Suas músicas expressavam percepçôes da vida cotidiana, do direito, da pátria, do pertencimento ao Brasil, das glórias da República, da cidadania, enfim. Eduardo das Neves não tinha vergonha de expor um patriotismo tido como "bizarro", na preconceituosa avaliação do famoso jornalista João do Rio.

Segundo Vagalume, de uma forma oposta a de João do Rio, "o povo se habituou a ouvir Eduardo das Neves cantar ao violão os acontecimentos de maior divulgação, ocorridos no cenário político da nossa Pátria”. Quando a Marinha de Guerra foi aumentada com os poderosos couraçados São Paulo e Minas Gerais, "o incomensurável artista” obteve um grande sucesso. Da mesma forma, quando criticara a Revolta de 6 de setembro de 1893, contra Floriano, ou o assassinato do grande Marechal Bittencourt. ${ }^{53}$ Seu estilo de compor, não fazendo separação entre as cenas, também ajudava esse estilo contador de histórias.

No obituário de Eduardo das Neves, no Correio da Manhã de 12 de novembro de 1919, apesar do reconhecimento de um certa extravagância em suas letras patriotas sobre o Marechal Bittencout e Santos Dumont, consideradas as mais vendidas dentre todas, respeitava a popularidade que alcançavam, pois "passaram logo ao domínio das ruas".

Eduardo das Neves era na verdade um contador e divulgador das histórias que todos os dias alimentavam a vida da cidade. Participava das novidades e das discussões políticas e republicanas de seu tempo através de seus versos publicados pela Editora Quaresma ou gravados pela Casa Edison. Parecia identificar com desenvoltura o poder e a abrangência dos novos veículos de comunicação. Se o " 5 de novembro" e o "Marechal de Ferro" não ganharam divulgação em disco, até porque eram fatos que já tinham ocorrido há algum tempo, Santos Dumont, os novos navios brasileiros e a homenagem a Rio Branco foram divulgadas em disco pela Casa Edison, mantendo o estilo e o tom patriótico das canções publicadas nos livros. ${ }^{54}$ 
Se eu estiver certa, temos mais uma indicação de que a indústria fonográfica manteve, ao menos nos primeiros tempos, a lógica da produção dos poetas de rua, que cantavam em versos os assuntos da ocasião. ${ }^{55}$ Manteve o estilo que Dudu comentou na introdução do seu livro Trovador da malandragem: "eu as faço (as modinhas) segundo a oportunidade, à proporção que os fatos vão ocorrendo, enquanto a coisa é nova e está no domínio público".

O "crioulo" Eduardo das Neves soube utilizar esse canal de expressão, ao mesmo tempo que dele foi resultante (talvez o melhor resultado). Certamente não estava sozinho. Além da Quaresma e da Casa Edison, os folcloristas do final do século XIX e início do XX registraram um número significativo de músicos e cantadores que, representantes de uma prática cultural popular disseminada por todos os cantos do país, discutiam o cotidiano através de versos e músicas, nas ruas, festas, circos populares, em edições simples e até mesmo na indústria fonográfica. A cultura das ruas invadia a indústria fonográfica com suas temáticas, estilos e pretensões.

De certo, o mundo da política transbordava nas canções populares e não só no sentido da pilhéria e do tribofe da política e do cotidiano. As canções valorizaram certos políticos, festejavam a pátria republicana, com a exaltação de seus heróis e certas datas nacionais, e integravam as regiōes do Brasil por meio do folclore musical. Eduardo das Neves fazia escolhas políticas e projetava-se como brasileiro e patriota na Primeira República. ${ }^{56}$

\section{Sobre a história das relações raciais e amorosas}

O patriota Eduardo das Neves era também um homem negro na jovem República. Se seus vínculos pessoais com o mundo da escravidão não estão claros, Dudu fez questão de não esquecer muitas conquistas dos escravos e a própria luta pela liberdade, em seus livros e discos. Para além dos heróis nacionais republicanos, para alem das canções sobre a cidade, a política e o cotidiano, Das Neves também contava e cantava, em versos e em música, a presença e a história dos afrodescendentes. A alforria, as relaçóes amorosas, as desigualdades raciais e a abolição estão presentes na maioria das vezes com muita ironia e humor.

Há uma série de sinais na obra de Dudu que também evidenciam a valorização da presença do negro na formação cultural brasileira, indicando que nem só de cânones literários, artísticos e musicais europeus teria vivido a chamada Belle Époque republicana. Nem só visões pessimistas sobre o Brasil e os produtos da mestiçagem estavam presentes no mercado editorial e cultural na capital da República. ${ }^{57}$

Ao acompanharmos suas músicas nas gravações da Casa Edison não é incomum ouvirmos ao fundo das gravaçôes, em tom alegre e divertido, suas vivas a crioulos e crioulas, e brincadeiras com os "baianos" ou o "baiano de guerra", como costumava chamar seu companheiro de gravaçôes. No final da música gravada sobre "o preto forro alegre", quando vão sendo cantadas de uma forma irônica as diferenças entre brancos e negros, é possível ouvir a expressão: “o crioulo mal chegou, já tá enrolando o Brasil, hein?”.

Não devemos perder de vista que o estilo cômico e irônico de Dudu pode ter sido a forma possível e permitida de se falar de identidade negra e criticar as desigualdades raciais naquele período. Aliás, essa era a sua arte mais aplaudida. Entretanto, mesmo nas canções sérias e com temáticas reconhecidas nos jornais como de grande importância, Eduardo das Neves não escondia sua cor, nem a história dos descendentes de escravos. Tenho alguns indícios para pensar isso, para além de suas próprias canções. $\mathrm{Na}$ publicação impressa do "hino" a Santos Dumont, a capa da partitura trazia, além da bela e parisiense Torre Eifel, uma pequena imagem de Dudu no canto alto esquerdo. Dudu parecia fazer questão de se mostrar como homem negro, elegante e vistoso.

Tenho notícias de que comparecia, ao lado de outros destacados artistas e homens públicos, às comemoraçōes pela Abolição da escravidão que aconteciam na cidade do Rio de Janeiro. No Jornal do Brasil de 1908, por exemplo, noticiava-se a presença de Das Neves, com canções, muitas delas "aplaudidíssimas", de seu repertório, nas programações de maio daquele ano. ${ }^{58}$ Em 1909, a Gazeta de Notícias registrava que Monteiro Lopes, reconhecido político negro, e Eduardo das Neves participaram juntos 
da programação oficiosa dos grandes festejos de maio. No enterro de José do Patrocínio, em janeiro de 1905, também organizado por Monteiro Lopes, Eduardo se apresentara, ao lado de Lopes Trovão, com suas modinhas ao violão e com uma poesia de Castro Alves ("Lúcia, a escrava").59

No mundo musical, podem ser identificadas canções, de autoria de Dudu ou de seu repertório, que valorizavam as heranças africanas (como os jongos) e as conquistas dos escravos (as amorosas e a própria liberdade). Com temas que abordavam as relações raciais e desafiavam as teorias racistas, que insistiam na inferiorização da população negra e mestiça, encontrei versos onde são cantadas as alforrias, as relações amorosas com iaiás e morenas, os encantos da mulata, a faceirice do crioulo, a valorização da cor preta frente às demais, as espertezas e ironias de Pai João, assim como um hino popular à própria Abolição. ${ }^{60}$

Nos livros Mistérios do violão e Trovador da malandragem as musas mulatas e morenas despontam em "Carmem" e "Albertina". ${ }^{61}$ "Roda Yáyá" é outra canção onde a mulata aparece cheia de feitiços e ligada ao diabo, deixando o cantor, provavelmente o próprio Dudu, "preso e morto", quase morrendo de sede. Chamando-se de "turuna", que significa um homem forte, poderoso e valente, provavelmente um capoeira, sentencia que "caindo na minha rede, das malhas [a mulata] não sairá" ${ }^{62}$ A tipologia da mulata sedutora, comum nos lundus mais eruditos, como já discuti em outro trabalho, ${ }^{63}$ mantém-se como referência de beleza e sensualidade nas composiçóes de Dudu. Mas, nos versos de sua autoria, a bela mulata caía mesmo na rede dos convencidos crioulos - e não na dos senhores brancos.

O orgulho do crioulo torna-se ainda mais desconcertante nos versos destinados às sinhazinhas. Considerando a hipótese da autoria ser sua, é significativo que um músico negro pudesse ser representado como podendo dirigir versos de encantamento a uma sinhazinha. Talvez aí residisse o centro da situação engraçada: a impossibilidade ou improbabilidade da relação podia produzir o riso. Ao mesmo tempo, contudo, a inversão sexual e racial da clássica relação de dominação (homem branco e mulher negra) cantada por Dudu agregava ao riso um inegável significado político.

Nesse encantamento pela Sinhá, Dudu destacava os seus belos olhos e o perfume. De tanto amor, pedia-lhe um beijo e chamava-a de "minha candonguinha". Em outra canção, "Sempre chorando", Dudu faz referência a uma suposta rivalidade entre "branquinhas e mulatinhas". Se pensarmos no Dudu das Neves como intérprete ou mesmo autor destes versos fica reforçada a imagem valorizada do crioulo, já bastante presente na sua música autobiográfica, balançando (ou se achando capazes de balançar) o coração das "branquinhas", e o quanto não descartava o amor das "mulatinhas". ${ }^{64}$ Entre outras coletâneas de lundus e modinhas publicadas, ou mesmo entre registros de folcloristas do final do século XIX, localizei muitas canções envolvendo sinhazinhas, embora não fique muito evidente ser negro o sedutor. As sinhás, presumidamente bem comportadas, parecem ter sido fontes importantes de inspiração para a canção popular em várias situações e grandes concorrentes das mulatas como musas da música popular do período.

No repertório gravado em discos por Eduardo das Neves, no período registrado pela Casa Edison entre 1907 e 1912, a temática do envolvimento entre negros e a sinhazinha reaparece também em alguns lundus, considerados pela gravadora de autoria desconhecida. No "Lundu gostoso", Das Neves cantava que iria "para a Bahia ver sua sinhá" e "comer o seu dendê". ${ }^{65}$ No lundu "Pai João", Eduardo das Neves trazia do passado escravista um figura literária muito cantada e contada: o preto velho que não fugiu, mas nem por isso perdeu sua força e audácia. Na canção gravada, Pai João não abria a porta de sua casa, por ordem de ninguém (nem do delegado, nem do inspetor), já que Caterina, sua esposa, já estava deitada. O cantor, pelo que ouvimos da gravação, também parecia rir e se divertir com o verso sobre o "dia de domingo" que, "quando o senhor" ia "passear", ficava "tomando conta de sua bela iaiá". ${ }^{66}$

Cançôes em que o protagonista era Pai João (ou algum outro Pai) não aparecem apenas nas gravações de Dudu, foram registradas por muitos folcloristas no período do pós-abolição e devem ter circulado em variados ambientes artísticos e sociais. ${ }^{67}$ Também engraçadas e irônicas, essas canções permitem perceber que, mesmo em situações por vezes desfavoráveis (e ridículas), eram projetados, como num jo- 
go de forças, a extensão do desejo dos escravos (e também das sinhás?), por um lado, e os limites ao respeito à autoridade dos senhores e futuros patrôes, por outro. A partir desse tipo de verso é possível propor que poetas como Dudu tematizavam a luta em torno da redefinição das relaçôes e das identidades raciais no período da Abolição e da pós-emancipação.

Na canção "Iaiazinha", Dudu parece levar mais longe a discussão do poder do homem negro. A solenidade da música gravada, quase uma declamação, ajuda a dar o tom provocador e irreverente, com palavras de duplo sentido, para revelar as intimidades entre um presumido escravo de confiança e sua senhora, através do cafuné. Em seus versos, Eduardo das Neves deixava evidente que não pretendia esquecer esses casos. Pelo contrário, parecia querer dar continuidade a essas relações, além de ajudar a divulgar suas possibilidades de uma forma bem ampla.

Eu tenho uma iaiazinha

Que quando está de maré

Me chama sempre em segredo

Pra me dar seu cafuné

Não sei que jeitinho tem

Por revirar dos dedinhos...

Ontem zangou-se toda

Por me ver cheirando a rapé...

Ficou deveras com raiva

E não me deu mais cafuné

Mas depois passado o momento

Serenado a raivazinha

Ela mesmo é quem me deu

$\mathrm{O}$ rapé, uma gaitinha...

Ai que gaitinha mimosa...

Descobri o melhor meio de ganhar meu cafuné... ${ }^{68}$

Através de uma direta linguagem sobre as desigualdades raciais, Eduardo das Neves gravou um dos maiores clássicos da poesia popular do período das lutas pela Abolição, ao menos pelos registros de vários folcloristas. Sob a forma de lundu, período em que o gênero só era menos gravado que a modinha, a canção recebeu o título de "Preto forro alegre", cujo nome é "Pai Francisco" ${ }^{69}$ Nesta gravação Eduardo das Neves reuniu versos de diferentes lundus que fazem parte do que Artur Ramos chamou de "folclore do Pai João". Sem dúvida, comparando-se como os versos publicados pelos folcloristas, a versão de Dudu veiculava críticas e ironias bem mais picantes.

Pelos versos gravados, incluindo as duas últimas frases, fica evidente o quanto estes lundus podiam falar da situação dos negros, que, através da música e da sátira, como em outras locais do "Atlântico Negro", desafiavam as ideologias, as hierarquias e as desigualdades raciais, reconstruídas depois da Abolição. Eduardo cantava as alegrias da conquista da alforria e as diferenças entre negros e brancos. Cantava vivas e "ulhas" à "minha crioula" e à "minha negra": "vem cá crioula assanhada"! Entre os versos sérios e solenes, cantados em "língua de preto", apresentava alguns em tom galhofeiro e engraçado, em ritmo de lundu bem rápido:

Quando eu vim da minha terra (estrofe recitada em forma solene)

Não comia qual peru

Chegando na terra de branco

Carne seca com angu 
Branco disse que negro fruta (estrofe recitada em forma solene)

Negro fruta com razão

Mas o branco também fruta

Com ar de capitão

Branco disse que não bebe (estrofe recitada em forma solene)

Nem vinho, nem bebe cana

Mas ai vê a garrafinha

Está em baixo da cama

E eu fico (estrofe-refrão cantada em ritmo de lundu)

Como um sarapatalho

Como um gambá

Quando cai em muro errado

O crioulo mal chegou (frase recitada no final da canção)

Já ta enrolando o Brasil, hein?

Na década da Abolição, ao lado de outros gêneros musicais e teatrais, o lundu, marcou a produção dos versos populares com suas desafiantes ironias, maliciosas críticas e letras de variados sentidos. Como definiu o paulista Rossini Tavares de Lima, um estudioso do lundu na década de 1940, este gênero era a canção satírica por excelência, "a única que censura ou ridiculariza pessoas, fatos, classes e demais aspectos da sociedade em que vivemos ou viveram nossos avós”..$^{70}$ Através das canções e interpretações de Dudu, esse tipo de lundu estava nos salōes, nos teatros, nas ruas, nos livros e na indústria fonográfica do início do século XX.

\section{Palavras finais}

Afonso Arinos, em elegante palestra feita em Petrópolis, em 26 de março de 1905, no salão do Club dos Diários, e publicada na revista Kosmos do mês seguinte, com o título de "A música popular" (portanto um pouco antes da publicação de João do Rio já comentada), deu destaque a Eduardo das Neves. Para um dos mais expressivos intelectuais brasileiros do período, Das Neves era um "trovador moderno" que, enquanto houvesse "alma sensível e acordes arrancados ao coração", continuaria a entoar as modinhas famosas. ${ }^{71}$

Como o editor Quaresma, Arinos tinha Eduardo das Neves em alta consideração. Além de um anônimo "bardo do povo" e um "moderno trovador", o cantor era visto como um instrumento de divulgação da "música democrática das modinhas, dos lundus, dos fandangos e tiranas". Mais ainda, para o ilustre escritor, era a "expressão espontânea de gênio de nosso povo", formado pelos principais povoadores de nosso solo, o português e o africano. A "toada brasileira [...] desde o tempo de Gregório de Mattos, no século XVII [...], já teria mostrado o seu cunho particular: misturava os tons nostálgicos da musa peninsular com os acentos bárbaros e cheios de desesperança dos cantares africanos e punhalhes em cima um sainete todo seu: o langor, o requebro e os momos da mestiça petulante". ${ }^{72}$

Afonso Arinos era um exemplo de intelectual que, como tantos outros, procurava, já no início do século XX, despertar nas plateias o "amor pelos cantares brasileiros" para melhor se conhecer o Brasil. ${ }^{73}$ Avaliava, muito antes dos chamados modernistas dos anos de 1920 e dos intelectuais ligados à política cultural do Estado Novo, que o riquíssimo "tesouro das tradiçôes nacionais" estava à espera de uma lapidação, evidentemente a cargo de ilustres poetas e compositores. ${ }^{74}$

Claro, entretanto, que todo essa valorização das "tradições musicais nacionais" exigiria uma separação entre o que havia de trigo e de joio - uma espécie de censura - nas "canções triviais". Afinal, "no desvario das orgias" poderiam estar acompanhadas de refrões ou coplas brutais e grosseiras. Para 


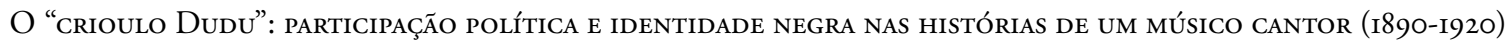

Martha Abreu

o autor, se a "musa popular era essencialmente ignorante, não deixava de ser profundamente genial". Eduardo das Neves, o "crioulo Dudu", foi colocado como peça-chave da campanha de valorização da música popular lançada por Afonso Arinos.

Entre intelectuais, editores, representantes da indústria fonográfica, empresários dos divertimentos e muitos artistas populares, as poesias e as canções populares ocupavam locais cada vez mais amplos e ganhavam novos e variados significados. Estavam nas ruas e atingiam um grande público. Eram ao mesmo tempo local de sociabilidade, bom negócio, oportunidade de trabalho, projeção social e objeto de disputa sobre as definições da nação. Ao lado de Afonso Arinos, João do Rio, Quaresma, Fred Figner, Catulo da Paixão Cearense e muitos outros, Eduardo das Neves foi protagonista da história da construção da música popular no Brasil contemporâneo.

Mas, lhe deu um sentido especial, ao procurar inserir-se, como homem negro, na Pátria republicana e ao registrar para a posteridade, através do verso e da música, as experiências e expressões da população negra e descendente de escravos. Eduardo das Neves, ao lado de outros músicos negros, representou, com sua trajetória e obra musical, um importante caminho de valorização dos artistas negros e combate ao racismo na Primeira República. Representou ainda, de uma forma próxima a de outros músicos dos Estados Unidos e do Caribe, algumas possibilidades de movimento e atuação política de homens negros no pós-abolição.

\section{Notas}

${ }^{1}$ Sobre essas versões ver ABREU, M. e DANTAS, C. V. Música popular, folclore e nação no Brasil, 1890-1920. In: CARVALHO, J. M. Nação e cidadania no Império: novos horizontes. Rio de Janeiro: Civilização Brasileira, 2007.

${ }^{2}$ ASSUNÇÃO, Matthias R. From Slave to Popular Culture: The formation of Afro-Brazilian Art Forms in nineteen century Bahia and Rio de Janeiro. Ibero Americana, III, 12, p. 159-176, 2003. Ver também WADE, Peter. Music, Race and Nation, Musica Tropical in Colombia. Chicago: Chicago Press, 2000; MOORE, Robin D. Nationalizing Blackness. Afrocubanismo and Artistic Revolution in Havana, 1920-1940. Pittisburgh: University of Pittisburghe Press, 1997.

${ }^{3}$ GILROY, Paul. O Atlântico Negro, modernidade e dupla consciência. Rio de Janeiro: UCAM/Editora 34, 2001, p. 189 e 245.

${ }^{4}$ DU BOIS, W. E. B. As almas da gente negra. Rio de Janeiro: Lacerda Ed., 1999, p. 299 (Tradução de Heloisa Toller Gomes).

${ }^{5}$ Idem, p. 308.

${ }^{6}$ Hebe Mattos desenvolve atualmente pesquisa sobre a "descoberta" da África por André Rebouças.

${ }^{7}$ Ver, por exemplo, ROBERTS, John W. From Trickster to Badman, The black folk hero in slavery and freedom, Philadelphia: University of Pennsylvania Press, 1990; BASCON, William. African folktales in the New World. Bloomington: Indiana University Press, 1992; CAPONI, G. The case for an African American Aesthetic. In: CAPONI, G. A reader in African American expressive culture. Massachusetts: The University of Massachusetts Press, 1999.

${ }^{8}$ Ver ABREU, M. Outras histórias de Pai João: conflitos raciais, protesto escravo e irreverência sexual na poesia popular, 1880-1950. Afro-Ásia, n. 31, 2004, p. 235-276. Em pesquisa recente, ao lado de Hebe Mattos, produzimos um DVD, sobre "Jongos, Calangos e Folias, música negra, memória e poesia”, onde também os versos ocupam lugar de destaque na construção da identidade negra. Ver http://www.historia.uff.br/jongos.

${ }^{9}$ Sobre a produção editorial de música nesse período, ver LEME, Mônica. E saíram à luz as novas polcas, modinhas, lundus e etc.: música popular e impressão musical no Rio de Janeiro (1820 - 1920). Tese de doutorado apresentada ao Programa de PósGraduação em História Social da UFF. Niterói, 2006.

${ }^{10}$ Segundo Franceschi, as letras podiam variar, mas as melodias eram muito semelhantes nas gravaçōes do início do século. $\mathrm{O}$ que mais importava era o assunto do momento. Quanto mais conhecida a melodia, maiores eram as chances de sucesso e venda. As publicações musicais em livro também demonstram que as melodias eram amplamente conhecidas, pois só eram publicadas as canções com as letras, sem as indicações musicais. Ver FRANCESCHI, Humberto. A Casa Edison e seu tempo. Rio de Janeiro: Sarapuí, 2002, p. 98. Há poucos estudos sobre as primeiras gravações no Brasil, mas pode ser destacada a pesquisa de Martha Tupinambá Ulhoa sobre os lundus gravados no início do século. Ver ULHÔA, M. T. Perdão Emilia! Transmissão oral e aural na canção popular. In: MATOS, C.; TRAVASSOS, E.; Medeiros, F. (Org.). Palavra cantada: ensaios sobre poesia, música e voz. Rio de Janeiro: 7Letras, 2008, p. 249-267.

${ }^{11}$ A indústria do disco no Brasil foi dominada, nos primeiros tempos, por Fred Figner, proprietário da Casa Edison. Esse empresário tinha parcerias com firmas do ramo sediadas nos Estados Unidos, Inglaterra e Alemanha. No início do século XX a maior empresa ligada a Fred Figner era a Talking Machine Odeon, que também tinha parcerias com empresários de 
várias cidades da América Latina. FRANCESCHI, op. cit., p. 94; COWLEY, John. Carnival, Canboulay and Calypso. Traditions in the making. New York, Cambridge University Press, 1996.

${ }^{12}$ Ainda são poucos os estudos sobre a trajetória de artistas negros ou mestiços no Brasil, entre o final do século XIX e início do XX, como Anacleto de Medeiros, Xisto Baia e Joaquim Calado. Mas já podem ser destacados, os trabalhos sobre o ator Vasques (MARZANO, Andrea Barbosa. Cidade em cena: o ator Vasques, o teatro e o Rio de Janeiro, 1839-1892. Rio de Janeiro: Ed. Folha Seca, 2008), e sobre Patápio Silva (OLIVEIRA, Maurício de Lima. Patápio Silva, o sopro da arte. Trajetória de um flautista mulato no início do século XX. 2007. Dissertação (Mestrado em História) - Universidade Federal de Santa Catarina). Sobre Catulo da Paixão Cearense, destaco duas dissertações de mestrado: FERLIN, Uliana Dias Campos (Mestrado em História, Unicamp, 2006) e CARVALHO, Marcio G. (Mestrado em História, UFF, 2006).

${ }^{13}$ SCULLY, Pamela e PATTON, Diana. Gender and Slave Emancipation in the Atlantic World. Durham and London: Duke University, 2005, p.1-34. Ver também CAULFIELD, Sueann. Em defesa da honra. Moralidade, modernidade e nação no Rio de Janeiro (1918-1940). Campinas: Ed. Unicamp, 2000.

${ }^{14}$ Esses dados estão na certidão de óbito, localizada no Arquivo da Santa Casa de Misericórdia do Rio de Janeiro. Entre os memorialistas há divergências. Jota Efegê afirma que Dudu era paulista e teria nascido em 1871. Baseia-se em informaçōes do prontuário de Eduardo das Neves no Corpo de Bombeiros. EFEGÊ, J., pseud. de João Ferreira Gomes. Figuras e coisas da música popular brasileira. Rio de Janeiro: Mec/Funarte, 1978, vol. 1, p. 178.

${ }^{15}$ Segundo Franceschi, que consultou os arquivos da Casa Edison, o cantor constava da folha de pagamento dos funcionários da Casa como um dos três da Seção de Gravação, recebendo Rs $100 \$ 000$ mensais. Os outros eram Baiano, com Rs $150 \$ 000$ e João Baptista Gonzaga com Rs 400\$000. Em uma carta do próprio Eduardo, escrita, em março de 1915, de Pelotas, onde estaria para uma excursão, o cantor refere-se a Figner como "digno patrão e amigo". Declarava ainda estar remetendo a quantia de $500 \$ 000$ (quinhentos mil réis) para depósito nas mãos do empresário, produto das economias conseguidas nesta viagem e que se destinavam a comprar a "casinha", e a do lado, onde morava em Piedade. Em 1915 Eduardo das Neves ainda não tinha tido recursos suficientes para comprar uma "casinha". Outra fonte de renda do autor era a venda das canções para Fred Figner. FRANCESCHI, op. cit., p.64.

${ }^{16}$ Além das referências citadas no texto, as principais referências sobre a biografia de Eduardo das Neves encontram-se em MARCONDES, Marcos. Enciclopédia da música brasileira. $2^{2}$ ed., São Paulo: Art. Editora, 1998; MAIS, Pedro Luís. Antologia da serenata. Rio de Janeiro: Simões editora, 1957; TINHORÃO, J. R. Circo brasileiro, local do universal. In: Cultura popular, temas e questôes. São Paulo: Ed. 34, 2001; VASCONCELOS, Ari. Panorama da música popular brasileira. Rio de Janeiro: Martins, 1964.

${ }^{17}$ Gerson, Brasil. História das ruas do Rio. 5a. ed. Rio de Janeiro: Lacerda Ed., 2000, p. 232.

${ }^{18}$ FRANCESCHI, op. cit., p. 67.

${ }^{19}$ Esse livro, quase de bolso, possui 96 páginas e anuncia na capa que os versos foram revistos por Catulo da Paixão Cearense. Catulo escreveu o Prefácio. Como só localizei esse livro recentemente, adio para uma próxima oportunidade uma análise mais detalhada.

${ }^{20}$ NEVES, Eduardo das, O trovador da malandragem. Rio de Janeiro: Livraria Quaresma Editores, 1926, p. 64.

${ }^{21}$ MEADE, Teresa. "Civilizing" Rio, reform and resistance in a brazilian city, 1889-1930. Pennsylvania: The Pennsylvania State University Press, 1997, p. 70-74.

${ }^{22}$ Em Mistérios do violão, Dudu apresenta outra canção com o título "crioulo faceiro", agora em homenagem ao "simpático clow Benjamin de Oliveira”. Benjamin foi um famoso palhaço negro.

${ }^{23}$ Jota Efegê, "O Jornal” de 3 de julho de 1966.

${ }^{24}$ MEADE, op. cit., p. 82 e 98.

${ }^{25}$ EFEGÊ, Jota. Figuras e coisas da música popular brasileira. Rio de Janeiro: Funarte, 1978, p. 178.

${ }^{26}$ GUIMARÃES, Francisco (O Vagalume). Na roda de samba. Rio de Janeiro: Funarte, 1978 (publicado em 1933), p. 6575. Mesmo que sempre identificado com o lundu, Vagalume conferiu local de destaque para Eduardo das Neves em um livro fundador da história do samba no Brasil, publicado em 1933. Preocupado em definir um local "verdadeiro" e mítico do samba, - "A roda de samba" - o cronista foi enfático em afirmar que o cantor ali "sempre foi catedrático, desde os tempos de guarda-freio e daqueles bambas, daqueles que se garantiam e cujas pernas eram respeitadas numa batucada”. É importante registrar que Vagalume faz parte de uma primeira geração de memorialistas que estava preocupada em construir as raízes do samba. Nessa operação, os memorialistas escolhiam os precursores e disputavam versôes sobre a "verdadeira” origem do samba. Ver NAPOLITANO, M. e WASSERMAN, M. C. Desde que o samba é samba: a questão das origens no debate historiográfico sobre a música popular brasileira. Revista Brasileira de História, São Paulo: v. 20, n. 39, p. 167-189, 2000. Apesar da "lembrança" de Vagalume, Eduardo das Neves foi em grande parte esquecido pelas histórias da música popular. Não pretendo aprofundar essa discussão no momento, mas disputas entre o lundu (gênero de Dudu) e o samba, ou disputas em torno da construção da autoria podem, num primeiro momento, ajudar a pensar esses esquecimentos. 
${ }^{27}$ No carnaval de 1917, em 21 de fevereiro, quando Vagalume trabalhava na redação, o Jornal do Brasil registra a visita de Eduardo das Neves com o Bloco da Casa Edison. Na despedida, versejava: "Com este punho na mão, me sinto forte e viril! Erguendo uma saudação, ao Jornal do Brasil. Amigos, por estar cantando, não fiques com ciúme. Aqui venho para saudar, ao Jornal e ao Vagalume”. Ver Jota Efegê, O Jornal, 28 de novembro de 1963. As visitas de blocos e cordões aos jornais, em busca de legitimidade, eram muito comuns na época do carnaval (CUNHA, Clementina P. Ecos da folia, uma história social do carnaval carioca (1890-1920). São Paulo: Cia das Letras, 2001).

${ }^{28}$ Idem, p. 73.

${ }^{29}$ Franceschi reproduziu um cartão de visitas de Eduardo das Neves: "Cantor oficial da casa Edison, Rio de Janeiro. Aceita contratos para teatros, parques, cinemas, cafés concertos, bares etc. Guarda-roupa a caráter”. FRANCESCHI, op. cit., p. 66.

${ }^{30}$ GUIMARÃES (O Vagalume), op. cit., p. 73, (publicado em 1933).

${ }^{31}$ A possível amizade com o famoso criminalista Evaristo de Moraes, apesar das evidentes diferenças entre eles, reforça a perspectiva que defendo sobre as preocupaçōes de Dudu com as lutas contra o racismo na Primeira República. Na biografia de Evaristo de Moraes, Joseli Mendonça aponta para a atuação de Moraes na mesma direção. MENDONÇA, J. M. N. Evaristo de Moraes, Tribuno da República. Campinas: Ed. Unicamp. 2007, parte II.

32 Arquivo Almirante, Museu da Imagem e do Som, 1965, Pasta Eduardo das Neves.

${ }^{33}$ Idem.

${ }^{34}$ EDMUNDO, Luiz. De um livro de Memórias, Rio de Janeiro: Departamento de Imprensa Nacional, 1958, p. 644. Ver também BESSONE, Tânia. Palácio dos destinos cruzados: bibliotecas, homens e livros no Rio de Janeiro, 1870-1920. Rio de Janeiro, Arquivo Nacional, 1997; AL FAR, Alessandra. Páginas de sensação: Literatura popular e pornográfica no Rio de Janeiro (1870-1924). 1 1e ed. São Paulo: Companhia das Letras, 2004.

${ }^{35}$ EDMUNDO, op. cit., p. 733-735.

${ }^{36}$ BROCA, Brito. A vida literária no Brasil, 1900. Rio de Janeiro: José Olympio, 1976. Segundo Brito Broca, a editora havia sido fundada por Pedro da Silva Quaresma, que se dedicou a publicar livros amenos, de interesse prático e ao alcance de qualquer um. As brochuras eram vendidas por preços módicos. Para Broca, escritores de terceira categoria lhe forneciam o material. Suas publicações espalharam-se por todo o Brasil, nos sertões da Bahia e Minas Gerais.

${ }^{37}$ EDMUNDO, op. cit., p. 407.

${ }^{38}$ As gravações da Casa Edison podem ser acessadas on-line pelo site do Instituto Moreira Sales. Fazem parte dos Acervos José Ramos Tinhorão e Humberto Franceschi.

${ }^{39}$ A Casa Edison comprava as canções de cada compositor e poderia dispor delas como bem entendesse.

${ }^{40} \mathrm{Nas}$ suas publicações, algumas vezes assume a autoria das canções. Outras vezes, sem declarar o autor, apenas comenta ser de seu repertório. Nas gravações da Casa Edison, a maior parte das canções cantadas por Eduardo das Neves está sem autoria. Localizei 165 canções gravadas por Eduardo das Neves no arquivo musical do Instituto Moreira Sales.

${ }^{41}$ RIO, João do. A alma encantadora das ruas. Rio de Janeiro: Secretaria Municipal de Cultura, Dep. Geral de Documentação e Informação Cultural, 1987, p. 173-186.

${ }^{42}$ Sobre o teatro de revistas, ver, dentre outros, GOMES, Tiago de M. Um espelho no palco, identidades sociais e massificação da cultura no teatro de revista dos anos 1920. Campinas: Ed. Unicamp, 2004.

${ }^{43}$ MORAIS, Renata Figueiredo. Os 13 de maio: A abolição na escrita de Duque Estrada. Dissertação de mestrado apresentada ao Programa de Pós-Graduação em História Social da Universidade Federal Fluminense. Niterói, 2007.

${ }^{44}$ José Murilo já defendeu essa ideia no livro Cidadania no Brasil, ao comentar que a Guerra havia trazido um esboço de sentimento de identidade nacional. CARVALHO, J. M. Cidadania no Brasil, o longo caminho. 8a ed., Rio de Janeiro: Civilização Brasileira, 2006, p. 38.

${ }^{45}$ NEVES, Trovador, op. cit., p. 33.

${ }^{46}$ Não é meu objetivo aprofundar as já longas discussões historiográficas sobre os significados do governo de Floriano, apenas registrar a sua popularidade. De acordo com o memorialista Luiz Edmundo, que também era um admirador, havia um certo fanatismo popular por Floriano (o Perfeito, o Prodigioso, Insubstituível). Na sua morte, um terço ou mais da população da cidade teria comparecido ao funeral. EDMUNDO, Luiz. De um livro de memórias. Vol 2. Rio de Janeiro: Dep. Imprensa Nacional, 1958, p. 353-407.

${ }^{47}$ Trovador popular moderno, extraordinária e completa coleção de modinhas brasileiras, do repertório dos aplaudidos trovadores Eduardo das Neves e Baiano e outros conhecidos artistas. 16a Edição, São Paulo: C. Teixeira e cia., 1926, p. 31 e 32.

${ }^{48}$ Essa canção foi analisada de uma forma mais detalhada em ABREU M. e MARZANO, A. Entre palcos e músicas, caminhos da cidadania no início da República. In: CARVALHO, J. M. e NEVES, L. M. B. P. (Org.). Repensando o Brasil dos oitocentos. Rio de Janeiro: Civilização Brasileira, 2008. 
${ }^{49}$ A análise do repertório de Eduardo das Neves contribui efetivamente, ao lado de outras pesquisas próximas, para a revisão da ideia de uma República Velha no Brasil. Seu patriotismo cantado em versos talvez possa ser apontado como um forte motivo para ele ter sido esquecido a partir de 1930. Para uma discussão sobre as memórias construídas sobre a Primeira República, ver GOMES, Ângela de Castro e ABREU, M. Apresentação do Dossiê “A nova 'velha’ República”. Revista Tempo, vol. 13, N. 26, 2009, p. 11-24.

${ }^{50}$ Essa crônica também foi publicada, em 1908, no livro de RIO, João do. A alma encantadora das ruas. Rio de Janeiro: Secretaria Municipal de Cultura, Dep. Geral de Documentação e Informação Cultural, 1987, p. 173-186.

${ }^{51}$ Evidentemente, esse patriotismo "bizarro" estava presente também entre os setores eruditos. Como exemplo, ver os inúmeros poemas publicados por PINHEIRO, XAVIER (Org.), A Música Cívica, Antologia brasileira destinada às escolas primárias da República. Rio de Janeiro: Livraria Editora de Leite Ribeiro \& Maurillo, 1920 (664 páginas). Sobre Floriano Peixoto, por exemplo, são registradas 35 homenagens em poesia. Os versos de Eduardo das Neves não foram citados. Agradeço a Marcos Luiz Bretas pela indicação desse livro.

52 MAGALHÃES, Marcelo. Ecos da Política: A capital federal, 1892-1902. Tese de Doutorado apresentada ao Programa de Pós-Graduação em História Social da UFF. Niterói, 2004.

${ }^{53}$ GUIMARÁES (O Vagalume), op. cit. p. 70 (publicado em 1933).

${ }^{54}$ Deve-se observar que o número de canções gravadas que tinham sido publicadas em livro é pequeno. Não é ainda possível explicar completamente essa constatação. Sem dúvida, pode-se levar em consideração que quando a indústria fonográfica se expande, na primeira década do século XX, os versos teriam que ter outras temáticas, pois as canções publicadas no final do século XIX se referiam a assuntos que, em grande parte, já tinham passado.

${ }^{55}$ A circulação de linguagens e temáticas populares na grande imprensa, entre o final do século XIX e início do XX, foi mostrada por HALL, Stuart. Da diáspora. identidades e mediaçôes culturais. Belo Horizonte: Editora da UFMG; Brasília: Representação da UNESCO no Brasil, 2003, p. 247-264.

${ }^{56}$ Ver ABREU M. e MARZANO, A. op. cit.

${ }^{57}$ Sobre essa perspectiva ver ABREU, M. e DANTAS, C. V. op. cit.

${ }^{58}$ Agradeço a Renata Moraes essas indicaçōes do Jornal do Brasil dos dias 13 e 15 de maio de 1909.

59 Agradeço a Carolina Vianna Dantas, que desenvolve trabalho sobre Manoel da Motta Monteiro Lopes, essas indicações.

${ }^{60}$ Para uma análise desse hino da Abolição, a Canoa Virada, ver ABREU E MARZANO, op. cit., p. 143-145.

${ }^{61}$ NEVES, "Mistérios", op. cit., p. 46 e 47, e "O trovador", op. cit., p. 33.

${ }^{62}$ NEVES, "Mistérios", op. cit., p. 28. Logo abaixo do título da canção o autor escreveu: "resposta à cançoneta Roda Yôyô".

${ }^{63}$ ABREU, M. "Sobre mulatas orgulhosas e crioulos atrevidos": conflitos raciais, gênero e nação nas canções populares (Sudeste do Brasil, 1890-1920). Revista Tempo, vol 8, n. 16, p. 143-173.

${ }^{64}$ NEVES, Mistérios, op. cit., p. 57e 58.

${ }^{65}$ Lundu Gostoso, Odeon, 108673, 1907-1912.

${ }^{66}$ Pai João, Odeon, 108075, 1907-1912.

${ }^{67}$ ABREU, M. Outras histórias, op. cit., p. 235-276.

${ }^{68}$ Iaiazinha, Odeon, 108074, 1907-1912. Versos muito próximos aos gravados por Eduardo das Neves, envolvendo os cafunés de iaiá, foram citados por Gilberto Freyre, a partir de referência de Pereira da Costa, com o seguinte comentário: "às vezes a iaiá branca catava os piolhos da mucama e do malungo". Ver FREYRE, Gilberto, Sobrados e mucamos, 2o tomo, Rio de Janeiro, José Olympio ed., 1985 (7aㅡ ed.), p. 467.

69 "Preto forro alegre", Odeon, no 120351, 1912-1913. No índice do acervo do Instituto Moreira Sales a autoria é atribuída a Das Neves, mas a canção é reconhecidamente de domínio público.

${ }^{70}$ LIMA, Rossini Tavares, Da conceituação do Lundu. São Paulo: s/ed. 1953, p. 7.

${ }^{71}$ Kosmos, ano 2, no 4, abril de 1905, p. 5.

${ }^{72}$ Idem, p. 2 e 3.

${ }^{73}$ Ver, por exemplo, Mello Moraes Filho, Silvio Romero, Leonardo Motta, Alexina de Magalhães, dentre outros.

${ }^{74}$ Kosmos, ano 2, no 4, abril de 1905, p. 4. 


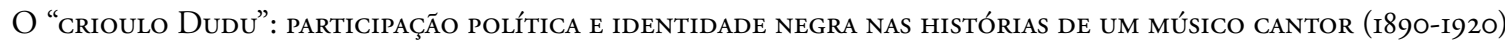

Martha Abreu

\title{
RESUMO
}

A partir da trajetória, das composições e do repertório musical de Eduardo Sebastião das Neves, conhecido como o "Crioulo Dudu", pretendo discutir as possibilidades de expressão política de um músico negro na Primeira República. Levando em consideração os debates em torno do Atlântico Negro, o crescimento do mercado editorial e da indústria fonográfica, foi possivel situar Eduardo das Neves como um produtor atuante do campo musical popular que se construía entre o final do século XIX e início do XX. Dudu conferiu ao mundo musical dimensóes politicas especiais, ao criar e divulgar cançôes que valorizavam o patriotismo e discutiam, de uma forma irônica e irreverente, as relaçôes raciais e a identidade do homem negro no pós-abolição. O exame da trajetória e da obra musical de Dudu permite repensar antigas concepçôes sobre participação política e identidade negra na Primeira República.

Palavras-chave: música popular, relaçôes raciais, identidade negra, Primeira República, patriotismo.

\begin{abstract}
Using the trajectory of Eduardo Sebastiāo das Neves, known as "Crioulo Dudu" ("Black Dudu", or "Creole Dudu"), as well as his compositions and musical repertoire as a starting point, this essay discusses the possibilities of black musician political expression during the Brazilian First Republic. Taking into account the debates on the Black Atlantic, the growth of publishing market and recording industry, it was possible to locate Eduardo das Neves as an active producer in the field of popular music that was being built between the late nineteenth and early twentieth centuries. Dudu gave special political dimensions to the music world by creating and disseminating songs that valorized patriotism and that discussed race relations and black identity in the post-emancipation period in an ironic and irreverent way. To examine Dudu's trajectory and musical work allows rethinking some established views on political participation and black identity during the First Republic.

Keywords: popular music, race relations, black identity, First Republic (Brazil), patriotism.
\end{abstract}

